\title{
Distal approach for percutaneous radiofrequency thermocoagulation of lumbar medial branches in patients with lumbar facet arthropathy: A retrospective analysis
}

\author{
Lomber faset artropatili hastalarda lomber medial dalların perkütan \\ radyofrekans termokoagülasyonu için distal yaklaşım: \\ Retrospektif bir analiz
}

(1) Tülin ARICl,1 (i) Ertuğrul KILIÇ²

\begin{abstract}
Summary
Objectives: Lumbar facet (zygapophysial) arthropathy is a common cause of chronic lower back pain, and percutaneous radiofrequency denervation of the facet joints appears to be an effective treatment that yields long-term improvement. A technique utilising a distal approach to place the needle parallel to the medial branch has recently come into common use. In the present study, a technique incorporating a distal approach and an A-P fluoroscopic view was investigated.

Methods: In this study, clinical charts of 164 patients with lumbar facet syndrome who had undergone RFTC (radiofrequency thermocoagulation) of facet-joint medial branches were retrospectively evaluated. The success rate of percutaneous radiofrequency thermocoagulation of facet-joint medial branches performed utilising a distal approach with an A-P view was evaluated. NRS (numeric rank score) pain scores and subjective patient-reported global responses were measured.

Results: Of the patients, responses were rated as excellent by 46 (28.0\%), good by 67 (40.8\%), fair by 21 (12.8\%) and poor by $30(18.2 \%)$. The median duration of pain relief was 7.3 months. In the 113 patients who reported excellent or good responses, the median duration of pain relief was 10.2 months.

Conclusion: Radiofrequency thermocoagulation for facet arthropathy is a safe and effective treatment option that is welltolerated. We suggest that a distal approach with an A-P view for facet radiofrequency thermocoagulation is a viable alternative to other approaches.
\end{abstract}

Keywords: Distal approach; lumbar facet arthropathy; radiofrequency thermocoagulation.

\section{Özet}

Amaç: Lomber faset (zigapofiziyal) artropati, kronik bel ağrısının yaygın bir nedenidir ve faset eklemlerinin perkütan radyofrekans denervasyonunun uzun vadeli iyileşme sağlayan etkili bir tedavi olduğu görülmektedir. İğneyi medial dallara paralel yerleştirmek için distal bir yaklaşım kullanan bir teknik son zamanlarda yaygın bir şekilde kullanılmaktadır. Bu çalışmada, distal bir yaklaşım ve A-P floroskopik görünümü içeren bir teknik araştırıldı.

Gereç ve Yöntem: Faset eklem medial dallarında, RFTC (radyofrekans termokoagülasyon) uygulanan lomber faset sendromlu 164 hastanın klinik tabloları retrospektif olarak değerlendirildi. A-P görünümüyle distal bir yaklaşım kullanılarak gerçekleştirilen faset-eklem medial dallarının perkütan radyofrekans termokoagülasyonunun başarı oranı değerlendirildi. NRS (numerik rank scoru) ağrı skorları ve subjektif global değerlendirme skorunda cevaplar ölçüldü.

Bulgular: Hastaların yanıtları, çok iyi 46 (\%28.0), iyi 67 (\%40.8), orta 21 (\%12.8), kötü 30 (\%18.2) olarak değerlendirildi. Ortalama ağrının sonlanma süresi 7.3 aydı. Çok iyi veya iyi yanıtlar veren 113 hastanın ortalama ağı rahatlama süresi 10.2 aydı.

Sonuç: Faset artropatisi için radyofrekans termokoagülasyon, iyi tolere edilen güvenli ve etkili bir tedavi seçeneğidir. Faset Radyofrekans termokoagülasyonu için A-P görüntüsü ile distal bir yaklaşımın diğer yaklaşımlara uygulanabilir bir alternatif olduğunu düşünüyoruz.

Anahtar sözcükler: Distal yaklaşım; lomber faset artroplasti; radyofrekans termokoagülasyon.

'Department of Algologia, Dr. Ersin Arslan Training and Research Hospital, Gaziantep, Turkey ${ }^{2}$ Department of Anesthesia, Şehitkamil State Hospital, Gaziantep, Turkey

Submitted (Başvuru tarihi) 09.05.2019 Accepted after revision (Düzeltme sonrası kabul tarihi) 18.09.2019 Available online date (Online yayımlanma tarihi) 13.01.2020

Correspondence: Dr. Ertuğrul Killç. Sehitkamil Devlet Hastanesi, Gaziantep, Turkey.

Phone: +90 - 533 - 6304875 e-mail: drertugrulkilic@yahoo.com

(- 2020 Turkish Society of Algology 


\section{Introduction}

Lumbar facet (zygapophysial) arthropathy is a common cause of chronic lower back pain and has a prevalence of $15 \%$ to $45 \%$ among causes of chronic lower back pain. ${ }^{[1-3]}$ Facetogenic pain is an axial nonradicular pain that is typically invoked by extension of the spine and spreads to the buttocks, hips, and legs above the knee. There are several treatment options for pain due to facet arthropathy, including pharmacotherapy, physical therapy, intra-articular injections, medial branch blocks, and radiofrequency neurotomy of the medial branch. ${ }^{[4,5]}$

The facet joint is innervated by medial branches of the dorsal ramus of the nerve root at L1-L4 levels and the dorsal ramus at $\mathrm{L} 5$ level. The $\mathrm{L} 5$ dorsal ramus differs from the other lumbar primary rami and is much longer. Each facet joint is innervated by medial branches of the same level and the level above. ${ }^{[6-8]}$

Percutaneous radiofrequency denervation of the facet joints appears to be an effective treatment that yields long-term improvement, and it is also commonly performed for the treatment of chronic lower back pain. ${ }^{[9-11]}$ Facet joint denervation was first described by Shealy ${ }^{[12]}$ in 1975 . Since then, fluoroscopy-guided medial branch RFTC (radiofrequency thermocoagulation) has been commonly used, and the technique has been modified extensively since its inception. The most commonly used technique for percutaneous RFTC of facet-joint medial branches has been the 'tunnel vision' approach. ${ }^{[13,14]}$ In this technique, a needle is placed at a target point perpendicularly, and it requires a traditional oblique view. When utilising the tunnel vision approach, the needle may also inadvertently come into contact with the dorsal root ganglion or the ventral ramus. ${ }^{[15]}$ The contact area between the tip of the needle and the medial branch is minimal. Placement of the needle parallel to the target medial branch can increase the contact area, resulting in greater efficacy. ${ }^{[16]}$

A technique utilising a distal approach to place the needle parallel to the medial branch has recently come into common use. ${ }^{[17]}$ Many studies utilising a distal approach have been reported in the literature. In almost all of these studies, an oblique or slightly oblique view has been used with the distal approach. To our knowledge, no reported study has utilised a distal approach in conjunction with a solely antero-posterior (A-P) view.

In the present study, a technique incorporating a distal approach and an A-P fluoroscopic view was investigated. The needle was placed distally to the target point on the skin and advanced towards the medial branch in a caudocephalad direction. Thus, the needle was placed parallel to the medial branch. This study aims to evaluate the success rate of percutaneous RFTC of facet-joint medial branches performed utilising a distal approach and an A-P view.

\section{Material and Method}

The current study was conducted at the Anesthesiology and Pain Clinic of the Dr. Ersin Arslan Training and Research Hospital from September 2015 to January 2017. This study was approved by the research Ethics Committee.

Between September 2015 January 2017, clinical charts of patients with lumbar facet syndrome who had undergone RFTC of facet-joint medial branches were retrospectively evaluated. Every patient had had pain for more than six months, predominantly in their lower back, with or without non-radicular radiation of the pain to the buttocks, hips, and legs above the knee, with no response to analgesic treatment or physical therapy. Lumbar magnetic resonance imaging or computerized tomography and plain Xray were performed in every patient to exclude other causes of lower back pain. The sample size was calculated to detect a $25 \%$ difference in 4 to 8 numerical rating scale (NRS) pain score in all patients from a baseline mean NRS (numeric rank score) of 7.2 with a standard deviation of 1.8. Patients who had undergone lumbar spinal surgery were not included in this study.

Two diagnostic facet blocks of the lumbar medial branches were performed using fluoroscopic landmarks. Block levels were identified via the patient's presentation, tenderness and radiology results. The first block was initiated with $0.5 \mathrm{ml}$ of $0.5 \%$ bupivacaine injected at each level using a 22-gauge Quincke-type spinal needle. Patients were evaluated with the NRS before and 30 minutes up to six hours after the procedure. The block was considered successful if $>80 \%$ pain relief was achieved. The second block 
initiated with $0.5 \mathrm{ml}$ of $2 \%$ lidocaine and a reduction in NRS score of at least $80 \%$ for $>1$ hour was deemed a positive response. Radiofrequency facet denervation was administered to the patients who exhibited positive responses to the two diagnostic blocks.

Facet denervetion was performed in the operating room under fluoroscopy. Patients were positioned in the prone position, and a pillow was placed under their abdomen to minimize lumbar lordosis. Standard monitoring (electrocardiography, non-invasive blood pressure and peripheric oxygen saturation) was utilised. Sedation with midazolam 1-2 mg was administered in all patients. The skin area was aseptically draped with sterile towels. The lumbar level was identified by counting upward from the sacrum or downward from $\mathrm{T} 12$. The $\mathrm{C}$-arm was positioned in an A-P view and tilted caudally or cephalad at each level in order to align the superior vertebral end plates. The skin entry point was marked over the superior border and medial edge of the transverse process, one level caudal for every lumbar level, excluding L5. For the L5 dorsal ramus, the entry point was at the level of the S1 posterior foramen.

The skin was anesthetized with $2 \%$ prilocine at each level. A disposable 20 gauge, $10-\mathrm{cm}$ radiofrequency cannula (Diros Technology Inc, Markham, Ontario, Canada) with a 5-mm active tip was advanced towards the junction between the superior articular process and the superior proximal edge of the transverse process under A-P fluoroscopic visualization for the L1-L4 medial branches, and the groove between the sacral alae and the superior articular process of S1 for the L5 medial branches in a caudo-cephalad direction. After contacting bone, the radiofrequency cannula was advanced slightly in a cranial direction and placed over the medial branch, parallel to it. The tip of the needle was not advanced beyond the ventral border of the anterior edge of the superior articular process in the lateral aspect to keep it away from the neural foramina.

After correct electrode positioning was confirmed in A-P (Fig. 1), oblique (Fig. 2), and lateral (Fig. 3) fluoroscopic views, sensory and motor stimulation were performed. After excluding the possibility that the proximity to the segmental nerve was too close, 0.5 $\mathrm{mL}$ of prilocaine $2 \%$ was injected through each elec-

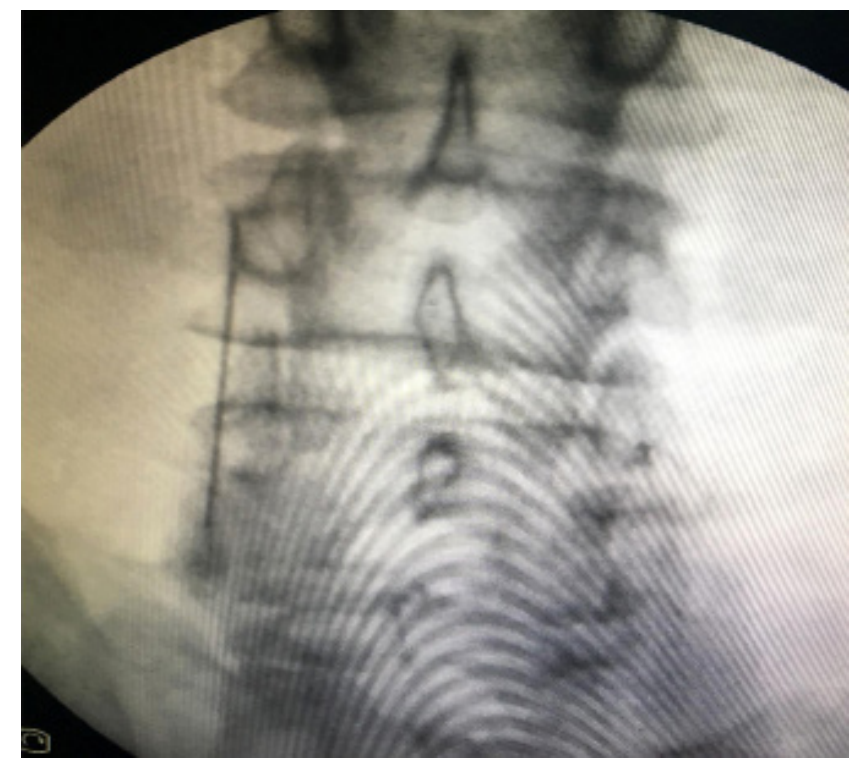

Figure 1. Anteroposterior view shows electrode positioned of the third lumbar medial branch at the $L 4$ transverse process.

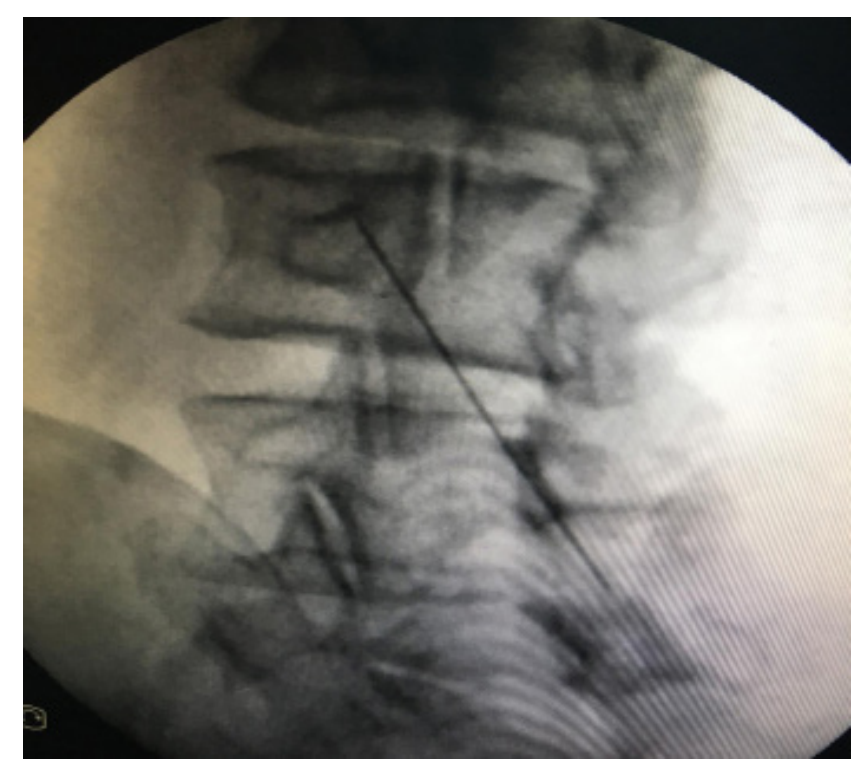

Figure 2. The oblique view shows electrode positioned of the third lumbar medial branch at the L4 transverse process.

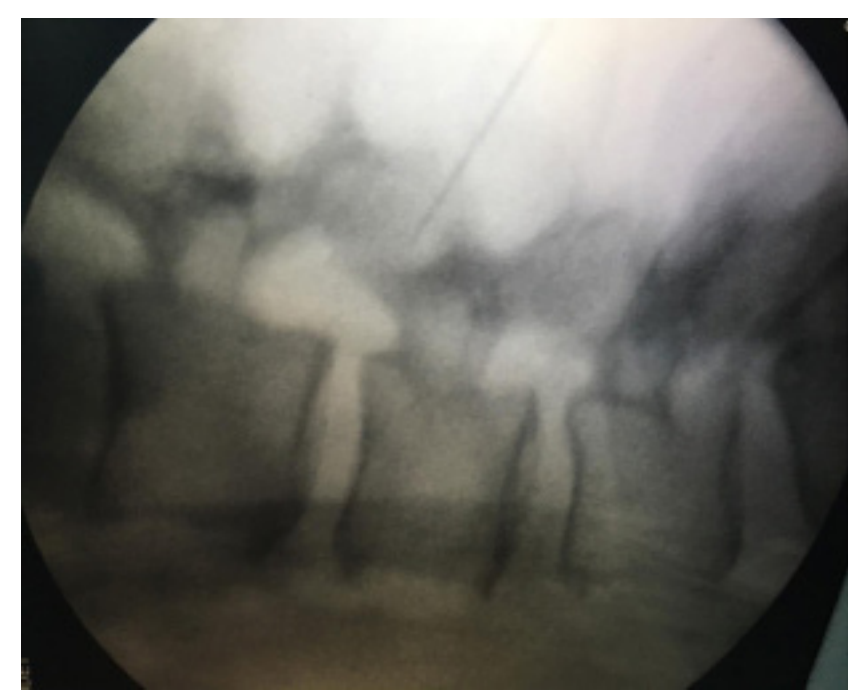

Figure 3. The lateral view shows electrode positioned of the third lumbar medial branch at the L4 transverse process. 
trode to achieve local anesthesia. Radiofrequency lesioning was performed at each target site at $80^{\circ} \mathrm{C}$ for 60 seconds using a radiofrequency generator (NeuroTherm NT1100, NeuroTherm INC. Ma01949 USA). Following the procedure, patients were observed for 30-60 minutes before being discharged. Patients were treated with analgesics for postprocedural pain.

After the radiofrequency procedure, patients were followed-up via periodic visits or telephone contact at 1, 3,6, 12 and 24 months. Outcome measures were NRS pain scores and subjective patient-reported global responses. Analgesic use was evaluated. Patients were asked about postprocedural complications, such as localized pain at the area where radiofrequency lesioning was performed, and sensory or motor deficits. Subjective patient-reported global responses were rated as excellent (>70\% improvement), good (50\%-70\% improvement), fair (30\%-49\% improvement), or poor (< than $30 \%$ improvement).

Success was defined as a pain reduction of at least $50 \%$. Demographic parameters and descriptive statistics of the variables were used.

\section{Results}

A total of 182 patients who underwent lumbar facet RFTC treatment for lower back pain were eligible during the 17-month study period. Of these, 164 patients were evaluated to follow-up and 18 were lost during the follow-up period. The baseline characteristics of the patients are shown in Table 1.

Of the patients who completed the study requirements, responses were rated as by 46 excellent (28.0\%), good by 67 (40.8\%), fair by 21 (12.8\%) and poor by 30 (18.2\%) (Table 2). The median duration of pain relief was 7.3 months. In the 113 patients who reported excellent or good responses, the median duration of pain relief was 10.2 months. The use of analgesics decreased in $65 \%$ of the excellent or good responders, while in fair and poor responders, there was no change in the use of analgesics.

Seventeen patients experienced mild, localized pain at the radiofrequency lesioning site and six patients reported paraesthesia in their lower back and buttocks. These symptoms resolved in approximately two to three weeks. During that period, the patients used analgesic medication (Diclofenac sodium). Twenty-two patients who were pain-free for at least six months after the first procedure underwent medial branch RFTC when their pain reoccurred.

\section{Discussion}

Previous studies suggest that percutaneous radiofrequency denervation of the facet joints is an effective treatment for chronic lower back pain. ${ }^{[10,11,17,18]}$ Manchikanti et al., ${ }^{[19]}$ in the analysis of the evidence, showed that radiofrequency denervation might reduce pain by $50 \%$ in at least $50 \%$ of patients. Dreyfuss et al. ${ }^{[20]}$ reported that $60 \%$ of the patients experienced pain relief of at least $90 \%$, and $87 \%$ experienced pain relief $60 \%$ for approximately 12 months.

Table 1. Demographics and clinical characteristics of the patients

\begin{tabular}{lc}
\hline & Mean \\
\hline Age (years) & 61 (range 41-85) \\
Female/male & $123 / 41$ \\
Pain duration (months) & 33,6 (range 7-45) \\
Preoperative NRS score & 7.2 (range 4-8) \\
Bilateral/unilateral (n) & $137 / 27$ \\
Opioid use (n) & 16 \\
\hline
\end{tabular}

NRS: Numerical Rating Scale.

Table 2. Results of lumbar medial branch radiofrequency denervation (global perceived effect)

\begin{tabular}{lcccc}
\hline & $\mathbf{n}$ & $\%$ & $\begin{array}{c}\text { Pain relief (average } \\
\text { duration; months) }\end{array}$ & $\begin{array}{c}\text { Pain relief } \\
\text { (range; months) }\end{array}$ \\
\hline Excellent & 46 & 28.0 & 10.7 & $6-24$ \\
Good & 67 & 40.8 & 9.8 & $5-20$ \\
Fair & 21 & 12.8 & 6.2 & $3-11$ \\
Poor & 30 & 18.2 & 2.6 & $0-6$ \\
\hline
\end{tabular}


Comparative diagnostic blocks using long-acting local anaesthetic and short-acting local anaesthetic are important for the diagnosis of facet joint pain. A single diagnostic block is not recommended because a false positive response may occur. ${ }^{[17,21]}$ When using single block only, the rate of false-positive responses is $25-41 \%{ }^{[22]}$ Thus, we used double diagnostic blocks before facet RFTC in the present study. Pain relief of at least $80 \%$ after the block is one of the strongest indicators of facet joint pain. ${ }^{[23,24]}$ Therefore, we chose a pain relief threshold of at least $80 \%$.

In a prospective clinical audit, Zhou et al. ${ }^{[25]}$ assessed $x$-ray-guided radiofrequency denervation in patients with lumbar facet joint syndrome. They reported that the denervation group had significantly lower pain scores after treatment than before treatment.

Facet RFTC has been studied extensively to improve the success of radiofrequency lesioning concerning various parameters, such as different electrode tips, stimulation parameters and technical practices. Accurate placement of the needle in medial branch RFTC is critical for the successful treatment of pain originating from a facet joint. A radiofrequency needle generates a lesion around the electrode, whereas the lesion is minor at the needle tip. ${ }^{[26]}$ It has recently been suggested that effective radiofrequency lesioning depends on the needle tip being parallel to the medial branch. ${ }^{[27,28]}$ There is also a longer distance to the target site when using the tunnel vision approach than when using the distal approach. ${ }^{[13]}$ Moon et al. ${ }^{[29]}$ compared an alternative distal approach with the tunnel vision approach and reported that patients who underwent facet RFTC using the distal approach felt less periprocedural pain. They used a distal approach in an ipsilateral oblique fluoroscopic view, while we used an A-P fluoroscopic view.

In a retrospective study Royal et al. ${ }^{[30]}$ assessed cervical and lumbar RFTC and reported respective responses to lumbar facet RFTC of excellent, good, fair and poor in 37 (30\%), $52(41 \%), 13(10 \%)$ and 22 (19\%), patients. However, they did not describe the technique they used. In that study, excellent responders reported an average duration of pain relief of 7.9 months (range 3-20 months), and good responders reported duration of 6.8 months (range 3-48 months). In the present study, respective responses of excellent, good, fair and poor were reported by 46 (28.0\%), 67 (40.8\%), 21 (12.8\%) and 30 (18.2\%) patients, which are similar results. In the present study, the median duration of pain relief in excellent responders was 10.7 months, and in good responders, it was 9.8 months.

In a prospective clinical audit, Gofeld et al. ${ }^{[31]}$ investigated the effects of facet RFTC for the relief of lower back pain in 174 patients and reported that $68.4 \%$ of them achieved good ( $>50 \%)$ to excellent $(>80 \%)$ pain relief lasting from six to 24 months, and $31.6 \%$ reported poor $(<50 \%)$ pain relief. They utilised a distal approach incorporating A-P fluoroscopy, but their skin entry point was somewhat lateral to the pedicle, whereas the skin entry point in the present study was over the superior border and medial edge of the transverse process, one level caudal. Thus, in the present study, the approach was more medial than the approach used in Gofeld et al.'s study. ${ }^{[31]}$

Arias $\mathrm{Garau}^{[32]}$ reported performing medial branch radiofrequency denervation of the lumbar spine with a 15 to 30-degree oblique entrance. Jacobson et al. ${ }^{[33]}$ performed bipolar radiofrequency facet ablation of the lumbar facet capsule in conjunction with conventional radiofrequency ablation. They used an A-P or slightly oblique fluoroscopic view.

We have been routinely using a distal approach and an A-P fluoroscopic view for facet RFTC in our clinical practice. Because the needle is not placed parallel to the fluoroscopy beam, a distal approach requires three-dimensional consideration. ${ }^{[34]}$ We think that a distal approach with an A-P view renders the procedure easier to perform and less painful than a distal approach with an oblique view because in the former, the distance to the target point is shorter. Clinically, it is also our impression that a distal approach with an A-P view is easier to perform and less painful than a tunnel vision approach when it is performed by experienced operators. Shuang et al. ${ }^{[35]}$ suggested that the distance between the dorsal ramus bifurcation and the superior proximal edge of the transverse process is approximately $3 \mathrm{~mm}$. Thus, when performing medial branch RFTC, the needle should not be advanced more than $3 \mathrm{~mm}$ to the superior proximal edge of the transverse process. In this re- 
spect, A-P view is safer than other views because the needle is not advanced in the medial aspect.

A complication rate of $1.0 \%$ per lesion site associated with facet RFTC with a tunnel vision approach was reported by Kornick et al. ${ }^{[36]}$ Dysaesthesia or hyperaesthesia in lumbar skin due to neuritis or spinal nerve damage is a potential side effect. ${ }^{[13]}$ In the present study, 17 patients experienced mild, localized pain at the radiofrequency lesioning site and 6 reported paraesthesia in their lower back and buttocks. These symptoms were resolved in approximately two to three weeks.

The present study had several limitations. First, this was a retrospective study, and our aim was to evaluate our results in comparison with the results of previous studies. Another limitation was that psychological state, functional capacity and quality of life were not evaluated in the present study.

\section{Conclusion}

RFTC for facet arthropathy is a safe and effective treatment option that is well-tolerated. We suggest that a distal approach with an A-P view for facet RFTC is a viable alternative to other approaches. Further studies are needed to investiagate the differences between a distal approach with an A-P view and other approaches and we think that some additional techniques for facet RFTC will be developed in future years.

Ethical Approval: The study was approved by SANKO University's Clinic Investigation Committee (2018-05).

Conflict-of-interest issues regarding the authorship or article: None declared.

\section{Peer-rewiew: Externally peer-reviewed.}

\section{References}

1. Boswell MV1, Shah RV, Everett CR, Sehgal N, McKenzie Brown AM, Abdi S, et al. Interventional techniques in the management of chronic spinal pain: evidence-based practice guidelines. Pain Physician 2005;8(1):1-47.

2. Sehgal N, Shah RV, McKenzie-Brown AM, Everett CR. Diagnostic utility of facet (zygapophysial) joint injections in chronic spinal pain: A systematic review of evidence. Pain Physician 2005;8(2):211-24.

3. Poetscher AW, Gentil AF, Lenza M, Ferretti M. Radiofrequency denervation for facet joint low back pain: a systematic review. Spine (Phila Pa 1976) 2014;39(14):E842-9.
4. Cohen SP, Raja SN.Pathogenesis, diagnosis, and treatment of lumbar zygapophysial (facet) joint pain. Anesthesiology 2007;106(3):591-614. [CrossRef]

5. Leggett LE, Soril LJ, Lorenzetti DL, Noseworthy T, Steadman $\mathrm{R}$, Tiwana S, et al. Radiofrequency ablation for chronic low back pain: A systematic review of randomized controlled trials. Pain Res Manag 2014;19(5):e146-53. [CrossRef]

6. Maus T. Imaging the back pain patient. Phys Med Rehabil Clin N Am 2010;21(4):725-66. [CrossRef]

7. Schmidt $\mathrm{H}$, Heuer F, Wilke HJ. Interaction between finite helical axes and facet joint forces under combined loading. Spine (Phila Pa 1976) 2008;33(25):2741-8. [CrossRef]

8. Bogduk N, Wilson AS, Tynan W. (1982) The human lumbar dorsal rami. J Anat 1982;134(Pt 2):383-97.

9. Manchikanti L. The growth of interventional pain management in the new millennium: a critical analysis of utilization in the medicare population. Pain Physician 2004;7(4):46582.

10. van Kleef $M$, Vanelderen $P$, Cohen SP, Lataster $A$, Van Zundert J, Mekhail N. Pain originating from the lumbar facet joints. Pain Pract 2010;10(5):459-69. [CrossRef]

11. Van Zundert J, Vanelderen P, Kessels A, van Kleef M. Radiofrequency treatment of facet-related pain: evidence and controversies. Curr Pain Headache Rep 2012;16(1):1925.

12. Shealy CN. Percutaneous radiofrequency denervation of spinal facets. Treatment for chronic back pain and sciatica. J Neurosurg 1975;43(4):448-51. [CrossRef]

13. Gofeld M, Faclier G. Radiofrequency denervation of the lumbar zygapophysial joints-targeting the best practice. Pain Med 2008;9(2):204-11. [CrossRef]

14. Nath S, Nath CA, Pettersson K. Percutaneous lumbar zygapophysial (facet) joint neurotomy using radiofrequency current, in the management of chronic low back pain: a randomized double-blind trial. Spine (Phila Pa 1976) 2008 May 20;33(12):1291-7. [CrossRef]

15. Sehgal A, Valentine JM. Lumbar radiculopathy after zygapophyseal joint injection. Br J Anaesth 2007;99(3):4124.

16. Lau P, Mercer S, Govind J, Bogduk N. The surgical anatomy of lumbar medial branch neurotomy (facet denervation). Pain Med 2004;5(3):289-98. [CrossRef]

17. Cohen SP, Williams KA, Kurihara C, Nguyen C, Shields C, Kim $P$, et al. Multicenter, randomized, comparative cost-effectiveness study comparing 0,1 , and 2 diagnostic medial branch (facet joint nerve) block treatment paradigms before lumbar facet radiofrequency denervation. Anesthesiology 2010;113(2):395-405. [CrossRef]

18. Richardson J. A (pain free) step in the right direction. $\mathrm{Br} J$ Anaesth 2004;93(2):173-4. [CrossRef]

19. Manchikanti L, Kaye AD, Boswell MV, Bakshi S, Gharibo CG, Grami V, et al. A systematic review and best evidence synthesis of effectiveness of therapeutic facet joint interventions in managing chronic spinal pain. Pain Physician 2015;18(4):E535-82.

20. Dreyfuss P, Halbrook B, Pauza K, Joshi A, McLarty J, Bogduk $N$. Efficacy and validity of radiofrequency neurotomy for 
chronic lumbar zygapophysial joint pain. Spine (Phila Pa 1976) 2000;25(10):1270-7. [CrossRef]

21. Sehgal N, Dunbar EE, Shah RV, Colson J. Systematic review of diagnostic utility of facet (zygapophysial) joint injections in chronic spinal pain: an update. Pain Physician 2007;10(1):213-28.

22. Curatolo $M$, Bogduk N. Diagnostic and therapeutic nerve blocks. In: Fishman SM, Ballantyne JC, Rathnell JP, editors. Bonica's management of pain. Philadelphia: Wolters Kluwer/Lippincott Williams and Wilkins; 2010. p. 1401-23.

23. Cohen SP, Hurley RW, Christo PJ, Winkley J, Mohiuddin MM, Stojanovic MP. Clinical predictors of success and failure for lumbar facet radiofrequency denervation. Clin J Pain 2007;23(1):45-52. [CrossRef]

24. North RB, Han M, Zahurak M, Kidd DH. Radiofrequency lumbar facet denervation: analysis of prognostic factors. Pain 1994;57(1):77-83. [CrossRef]

25. Zhou Q, Zhou F, Wang L, Liu K. An investigation on the effect of improved X-rays-guided radiofrequency thermocoagulation denervation on lumbar facet joint syndrome. Clin Neurol Neurosurg 2016;148:115-20. [CrossRef]

26. Bogduk N, Macintosh J, Marsland A. Technical limitations to the efficacy of radiofrequency neurotomy for spinal pain. Neurosurgery 1987;20(4):529-35. [CrossRef]

27. Leclaire R, Fortin L, Lambert R, Bergeron YM, Rossignol M. Radiofrequency facet joint denervation in the treatment of low back pain: A placebo-controlled clinical trial to assess efficacy. Spine 2001;26(13):1411-6. [CrossRef]

28. Cosman ER Jr, Dolensky JR, Hoffman RA. Factors that affect radiofrequency heat lesion size. Pain Med
2014;15(12):2020-36. [CrossRef]

29. Moon JY, Lee PB, Kim YC, Choi SP, Sim WS. An alternative distal approach for the lumbar medial branch radiofrequency denervation: A prospective randomized comparative study. Anesth Analg 2013;116(5):1133-40. [CrossRef]

30. Royal MA, Bhakta B, Gunyea I, Jenson M, Movva V, Taqi D, et al. Radiofrequency neurolysis for facet arthropathy: $A$ retrospective case series and review of the literatüre. Pain Pract 2002;2(1):47-52. [CrossRef]

31. Gofeld M, Jitendra J, Faclier G. Radiofrequency denervation of the lumbar zygapophysial joints: 10-year prospective clinical audit. Pain Physician 2007;10(2):291-300.

32. Arias Garau J. Radiofrequency denervation of the cervical and lumbar spine. Phys Med Rehabil Clin N Am 2018;29(1):139-54. [CrossRef]

33. Jacobson RE, Palea O, Granville M. Bipolar radiofrequency facet ablation of the lumbar facet capsule: An adjunct to conventional radiofrequency ablation for pain management. Cureus 2017;9(9):e1635. [CrossRef]

34. Kline MT, Yin W. Radiofrequency techniques in clinical practice. In: Waldman SD, editor. Interventional Pain Management. Philadelphia, PA: W.B. Saunders Company; 2001. p. 243-93.

35. Shuang F, Hou SX, Zhu JL, Liu Y, Zhou Y, Zhang CL, et al. Clinical anatomy and measurement of the medial branch of the spinal dorsal ramus. Medicine (Baltimore) 2015;94(52):e2367. [CrossRef]

36. Kornick C, Kramarich SS, Lamer TJ, Todd Sitzman B. Complications of lumbar facet radiofrequency denervation. Spine (Phila Pa 1976) 2004;29(12):1352-4. [CrossRef] 